\title{
PENGARUH DISIPLIN BELAJAR TERHADAP HASIL BELAJAR MATEMATIKA SISWA KELAS V SD NEGERI SEKECAMATAN KLIRONG TAHUN AJARAN 2020/2021
}

\author{
Anang Lufianto ${ }^{1}$, Ngatman $^{2}$, Moh. Salimi $^{3}$ \\ Universitas Sebelas Maret \\ lufiantoanang@gmail.com
}

\section{Article History}

accepted 1/11/2021

\begin{abstract}
Learning discipline is one of the factors affecting the student's mathematics learning outcomes.The study aimed to determine the effect of learning discipline on mathematics learning outcomes to fifth grade students of public elementary schools in Klirong Sub-district in academic year of 2020/2021 and to measure the contribution of learning discipline on mathematics learning outcomes to fifth grade students of public elementary schools in Klirong Sub-district in academic year of 2020/2021.Sampling method was cluster random sampling technique. Data analysis used SPSS application. The results indicated that there is an effect of learning discipline on mathematics learning outcomes to fifth grade students of public elementary schools in Klirong Sub-district. The value was ( $r=.433 ; R 2=.187$ ) and Sig. $0.000<$ 0.05 . This meant that the higher student's learning discipline, the higher student's mathematics learning outcomes, and vice versa. (2) The learning discipline contributed $18,70 \%$ on mathematics learning outcomes and the remaining $81,30 \%$ was influenced by other factors.
\end{abstract}

Keywords: learning discipline, learning outcomes, mathematics for elementary school

\begin{abstract}
Abstrak
Disiplin belajar merupakan salah satu faktor yang dapat memengaruhi tinggi rendahnya hasil belajar matematika siswa. Penelitian ini bertujuan untuk mengetahui adanya pengaruh disiplin belajar terhadap hasil belajar matematika siswa kelas V di SDN se-Kecamatan Klirong Tahun Ajaran 2020/2021 dan mengetahui besarnya sumbangan efektif disiplin belajar terhadap hasil belajar matematika siswa kelas V di SDN se-Kecamatan Klirong Tahun Ajaran 2020/2021. Pengambilan sampel dilakukan dengan teknik cluster random sampling. Data dianalisis menggunakan bantuan aplikasi SPSS versi 21. Hasil penelitian ini menunjukkan bahwa terdapat pengaruh disiplin belajar terhadap hasil belajar matematika siswa kelas $V$ SDN seKecamatan Klirong ditandai dengan nilai $\left(r=.433 ; R^{2}=.187\right)$ dan nilai Sig. $0,000<0,05$, yang artinya semakin tinggi disiplin belajar siswa, maka akan semakin tinggi pula hasil belajar matematika siswa, dan begitupun sebaliknya. Nilai sumbangan efektif variabel belajar terhadap hasil belajar matematika yaitu sebesar $18,70 \%$ dan sisanya sebesar $81,30 \%$ dipengaruhi oleh faktor lain.
\end{abstract}

Kata kunci: disiplin belajar, hasil belajar, matematika sekolah dasar 


\section{PENDAHULUAN}

Sekolah dasar merupakan jenjang paling dasar pada pendidikan formal yang ada di Indonesia. Jenjang sekolah dasar atau juga bisa disebut pendidikan dasar dalam Undang-Undang Sistem Pendidikan Nasional No. 20 Tahun 2003 Pasal 17 adalah jenjang pendidikan yang melandasi jenjang pendidikan menengah yang terdiri dari SD/MI 6 tahun dan SMP/MTs 3 tahun. Dalam pendidikan di sekolah dasar, siswa mempelajari berbagai disiplin ilmu atau mata pelajaran yang ada, salah satunya yaitu matematika.

Matematika diajarkan sejak jenjang sekolah dasar karena matematika merupakan disiplin ilmu yang erat kaitannya dengan masalah sehari-hari. Matematika juga memliki peran dalam era modern sekarang yang dapat mendasari berbagai disiplin ilmu untuk memajukan pola pikir manusia (Sujadi \& Wiyoto, 2011: 1). Pentingnya matematika pada era modern tentu mewajibkan adanya pengenalan matematika sedini mungkin yaitu melalui pembelajaran matematika pada jenjang sekolah dasar. Hal ini bertujuan untuk membiasakan siswa memecahkan masalah melalui pembelajaran matematika. Dengan adanya pembelajaran matematika di sekolah dasar, siswa menjadi terbiasa memecahkan soal atau masalah yang berhubungan dengan angka sehingga siswa terbiasa untuk berpikir kritis, logis, kreatif, dan dapat bekerja sama dengan baik (Wahyudi, 2015: 68).

Berdasarkan hasil riset tingkat penguasaan siswa sekolah dasar Indonesia terhadap mata pelajaran matematika masih tergolong rendah. Hal ini sesuai dengan hasil riset Trends in International Mathematics and Science Study (TIMSS) pada tahun 2015 menempatkan peringkat literatur matematika siswa Indonesia kelas IV berada pada peringkat 44 dari 49 dengan skor rata-rata yang diperoleh yaitu 397 jauh di bawah rata - rata skor internasional yang berada pada angka 500 menempatkan Indonesia berada pada kelompok rendah (<400) Puspendik (Novaliyosi \& Hadi, 2019: 563). Tingkat penguasaan matematika pada siswa sendiri dapat diukur dengan hasil belajar yang biasanya berupa nilai berwujud angka yang menunjukkan tingkat penguasaan siswa dalam mempelajari materi yang sudah diajarkan (Firmansyah, 2014: 92).

Hasil belajar pada siswa dapat dipengaruhi oleh berbagai faktor, baik faktor dari luar maupun dari dalam diri siswa. Salah satu yang dapat memengaruhi yaitu disiplin belajar yang merupakan faktor dari dalam diri siswa atau faktor endogen (Sobur, 2016). Disiplin belajar dapat dilakukan siswa dalam berbagai bentuk yang dapat dilakukan di sekolah maupun di rumah. Sikap disiplin belajar sendiri pada dasarnya merupakan sikap sadar siswa dalam menaati tata tertib dan perarturan yang berlaku (Ariefiani, 2013: 6).

Contoh dari sikap disiplin belajar dapat tercermin dari sikap siswa yang bersikap sopan santun, datang tepat waktu, mendengarkan penjelasan guru, mengerjakan PR dan lain-lain. Namun pada kenyataanya banyak siswa yang masih belum berdisplin dalam belajar. Hal ini karena masih banyak siswa yang yang telat mengumpulkan tugas, masih suka membuang sampah sembarangan, menggangu teman lain saat sedang belajar, mencontek pekerjaan teman, mengerjakan tugas dibantu atau dikerjakan oleh orang lain.

Setiap siswa harus memiliki sikap disiplin belajar karena dengan adanya disiplin belajar membuat belajar siswa lebih terarah. Hal ini sejalan dengan penelitian yang telah dilakukan oleh Rusni \& Agustan (2018: 8) juga menunjukkan adanya pengaruh yang signifikan kedisiplinan belajar terhadap terhadap hasil belajar matematika siswa sekolah dasar.

Tujuan penelitian ini yaitu untuk (1) mengetahui adanya pengaruh disiplin belajar terhadap hasil belajar matematika siswa kelas $\mathrm{V}$ di SDN se-Kecamatan Klirong Tahun Ajaran 2020/2021 dan (2) mengetahui besarnya sumbangan efektif disiplin belajar 
terhadap hasil belajar matematika siswa kelas $\mathrm{V}$ di SDN se-Kecamatan Klirong Tahun Ajaran2020/2021.

\section{METODE}

Penelitian ini merupakan penelitian kuantitatif dengan metode analisis regresi. Analisis regresi dilakukan untuk mengukur besarnya pengaruh antara satu variabel independen dengan satu variabel dependen dan memprediksi variabel dependen dengan menggunakan variabel independent (Priyatno, 2012: 24). Dalam penelitian ini, peneliti mencari pengaruh disiplin belajar terhadap hasil belajar matematika siswa kelas $\mathrm{V}$.

Populasi penelitian ini yaitu siswa kelas $V$ SDN se-Kecamatan Klirong sejumlah 847 siswa, sampel sebanyak 282 siswa, dan sampel yang diperoleh sebanyak 282 siswa di 11 SD Negeri di Kecamatan Klirong yang dipilih secara acak dengan teknik cluster random sampling dengan bantuan aplikasi Statistical Product and Service Solution (SPSS) versi 21.

Teknik pengumpulan data penelitian ini menggunakan angket dan soal. Instrumen yang digunakan yaitu angket disiplin belajar meliputi indicator mematuhi tata tertib sekolah, disiplin dalam prpses belajar, disiplin mengerjakan tugas, disiplin belajar di rumah, rajin dan teratur brlajar. Sedangkan soal yang digunakan yaitu soal matematika siswa kelas V semester ganjil tahun ajaran 2020/2021.

Uji prasyarat data penelitian ini menggunakan uji linieritas dan uji normalitas. Setelah memenuhi prasyarat, data dianalisis menggunakan uji korelasi dan regresi.

\section{HASIL DAN PEMBAHASAN}

Penelitian dilakukan dengan memberikan angket disiplin belajar kepada siswa kelas V di SD yang menjadi sampel penelitian dan soal matematika. Uji prasyarat data pada penelitian ini telah terpenuhi yaitu data berdistribusi normal dan data linier.

Tabel 1. Hasil Analisis Uji Normalitas Hasil Belajar Belajar Matematika dan Angket Disiplin Belajar

\begin{tabular}{cc|c|c} 
& \multicolumn{3}{c}{ Tests of Normality } \\
\hline & \multicolumn{3}{c}{ Kolmogorov-Smirnov ${ }^{\mathrm{a}}$} \\
\cline { 2 - 4 } & Statistic & Df & Sig. \\
\hline DISIPLIN BELAJAR &, 042 & 282 &, $200^{*}$ \\
\hline HASIL BELAJAR &, 052 & 282 &, 060 \\
\hline
\end{tabular}

a. Lilliefors Significance Correction

Pada penelitian ini diperoleh nilai signifikansi uji normalitas signifikansi metode Lilliefors Significance Correction sebesar 0,060 untuk data hasil belajar matematika, dan 0,200 untuk disiplin belajar. Nilai signifikansi pada kedua variabel tersebut menunjukkan lebih besar dari 0,05, sehingga data dikatakan berdistribusi normal. 
Tabel 2. Hasil Analisis Uji Linearitas Hasil Belajar Matematika dan Angket Disiplin Belajar

ANOVA Table

\begin{tabular}{|c|c|c|c|c|c|c|c|}
\hline & & & $\begin{array}{l}\text { Sum of } \\
\text { Squares }\end{array}$ & $d f$ & $\begin{array}{l}\text { Mean } \\
\text { Square }\end{array}$ & $F$ & Sig. \\
\hline & & (Combined) & 12568.050 & 32 & 392.752 & 3.302 & .000 \\
\hline & Between & Linearity & 7903.311 & 1 & 7903.311 & 66.441 & .000 \\
\hline $\begin{array}{l}\text { Hasil Belajar * } \\
\text { Disiplin Belajar }\end{array}$ & Groups & $\begin{array}{l}\text { Deviation } \\
\text { from } \\
\text { Linearity }\end{array}$ & 4664.739 & 31 & 150.475 & 1.256 & .167 \\
\hline & Within $\mathrm{Gr}$ & roups & 29619.003 & 249 & 118.952 & & \\
\hline & Total & & 42187.053 & 281 & & & \\
\hline
\end{tabular}

Berdasarkan uji linieritas diperoleh nilai Sig. Deviation from Linearity untuk variabel disiplin belaja terhadap hasil belajar matematika adalah 0,167. Nilai Sig. Deviataion from Linearity menunjukkan $>(0,05)$. Oleh karena itu data penelitian ini bersifat linier.

Setelah uji prasyarat analisis data telah terpenuhi, selanjutnya dilakukan analisis data uji hipotesis.

Tabel 3. Hasil Analisis Regresi Disiplin Belajar terhada Hasil Belajar Matematika

Model Summary

\begin{tabular}{lllll}
\hline Model & $R$ & $R$ Square & $\begin{array}{l}\text { Adjusted } \\
\text { Square }\end{array}$ & $\begin{array}{c}R \text { Std. Error of } \\
\text { the Estimate }\end{array}$ \\
\hline 1 & $.433^{\mathrm{a}}$ & .187 & .282 & 11.065 \\
\hline a. Predictors: (Constant), Disiplin Belajar &
\end{tabular}

Berdasarkan uji regresi yang telah dilakukan, pada tabel 3 dapat diketahui bahwa besarnya nilai korelasi/ hubungan $(R)$ yaitu sebesar 0,433 , dengan $r$ tabel sebesar 0,116 maka nilai $r$ hitung $(0,433)>r$ tabel $(0,116)$ artinya terdapat hubungan antara disiplin belajar dan hasil belajar matematika dengan koefisien korelasi berada pada tingkat hubungan moderat/sedang menurut tabel pedoman interpretasi koefisien korelasi versi De Vaus. Dan dari output tersebut diperoleh koefisien determinasi $(R$ Square) sebesar 0,187, yang artinya kontribusi disiplin belajar terhadap hasil belajar matematika adalah sebesar $0,187 \times 100 \%=18,70 \%$.

Tabel 4. Koefisien Regresi

\begin{tabular}{ccrrrr}
\hline \multicolumn{7}{c}{ Coefficients $^{\text {a }}$} & Sig. \\
& \multicolumn{2}{c}{$\begin{array}{c}\text { Unstandardized } \\
\text { Coefficients }\end{array}$} & $\begin{array}{c}\text { Standardized } \\
\text { Coefficients }\end{array}$ & $T$ & \\
\cline { 2 - 7 } & $B$ & Std. Error & Beta & & \\
\hline 1 (Constant) & .188 & 8.003 & & .023 & .981 \\
\hline Disiplin Belajar & .761 & .095 & .433 & 8.034 & .000 \\
\hline
\end{tabular}

a. Dependent Variable: Hasil Belajar

Tabel 4 tersebut menginformasikan model persamaan regresi yang diperoleh dengan koefisien konstanta dan koefisien variabel yang ada di kolom Unstandardized 
Coefficients $B$. Berdasarkan tabel di atas diperoleh model persamaan regresi linier sederhana:

\section{$Y=0,188+761 X$}

Hal ini menunjukkan bahwa setiap kenaikan skor disiplin belajar $(X)$ sebesar 1 poin, maka akan berpengaruh pula pada peningkatan hasil belajar matematika ( $\mathrm{Y}$ ) sebesar 0,761 dan tanda positif $\left(^{+}\right)$pada persamaan regresi menunjukan pengaruh postif antara variabel disiplin belajar dan variabel hasil belajar matematika.

Penelitian ini bertujuan untuk mengetahui adanya pengaruh disiplin belajar terhadap hasil belajar matematika siswa kelas $\mathrm{V}$ di SDN se-Kecamatan Klirong Tahun Ajaran 2020/2021. Berdasarkan output di atas dapat diketahui bahwa nilai signifkansi variabel disiplin belajar sebesar 0,000, karena nilai signifikansi lebih kecil dari 0,05 $(0,000<0,50)$ maka tolak Ho, sehingga terima Ha yang berbunyi bahwa ada pengaruh antara disiplin belajar dengan hasil belajar matematika siswa kelas V SDN seKecamatan Klirong tahun ajaran 2020/2021.

Besarnya pengaruh disiplin belajar terhadap hasil belajar matematika dihitung menggunakan sumbangan efektif. Sebelum melakukan perhitungan sumbangan efektif, peneliti terlebih dahulu mencari nilai koefisien determinasi, dan sumbangan relatif. Koefesien determinasi pada penelitian ini menggunakan rumus menurut Riduwan dan Sunarto (2013: 228) dapat dicari menggunakan rumus sebagai beikut:

$$
\mathrm{K}^{2}=x^{x} \mathrm{c}
$$

Dimana nilai $r$ telah diketahui yaitu $r=0,395$

$$
\begin{aligned}
\mathrm{KP} & =(0,433)^{2} \times 100 \% \\
& =0,187 \times 100 \% \\
& =18,70 \%
\end{aligned}
$$

Berdasarkan hasil perhitungan di atas, didapatkan nilai koefisien determinasi dalam persen yaitu 18,70\%, dengan koefisien determinasi sebesar 0,187 . Setelah diketahui nilai koefisien determinasi (R2), maka analisis selanjutnya yaitu mencari sumbangan relatif. Sumbangan relatif pada penelitian ini menggunakan rumus sebagai berikut.

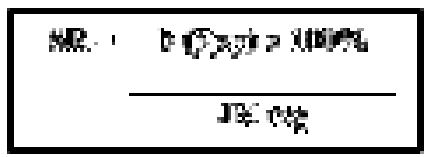

Peneliti menggunakan analisis regresi dengan aplikasi SPSS versi 21 untuk mencari nilai b dan JK reg, sedangkan untuk mencari jumlah xy peneliti menggunakan aplikasi MS. Excel. Hasil perhitungan $\sum x y$ yaitu 10.379. Berikut merupakan hasil analisis regresi:

Tabel 5. Hasil Analisis Nilai JK reg pada Uji Regresi

\section{ANOVA $^{\mathrm{a}}$}




\begin{tabular}{|c|c|c|c|c|c|c|}
\hline Model & & $\begin{array}{l}\text { Sum } \\
\text { Squares }\end{array}$ & $d f$ & $\begin{array}{l}\text { Mean } \\
\text { Square }\end{array}$ & $F$ & Sig. \\
\hline \multirow{3}{*}{1} & Regression & 7903.311 & 1 & 7903.311 & 64.547 & $.000^{\mathrm{b}}$ \\
\hline & Residual & 34283.742 & 280 & 122.442 & & \\
\hline & Total & 42187.053 & 281 & & & \\
\hline
\end{tabular}

a. Dependent Variable: Hasil Belajar

a. Predictors: (Constant), Disiplin Belajar

Berdasarkan tabel 5 dan tabel 4, didapatkan nilai JK reg sebesar 7903.311 dan nilai b sebesar 0,761 , maka sumbangan relatif dapat dicari menggunakan rumus:

$$
\begin{aligned}
& S R=\frac{0,761(10379) \times 100 \%}{7903.311} \\
& S R=100 \times 100 \% \\
& S R=100 \%
\end{aligned}
$$

Analisis selanjutnya yaitu mencari sumbangan efektif. Dari perhitungan diatas didapatkan nilai $S R$ sebesar $100 \%$ dan $R^{2}$ sebesar 0,187 . Maka SE dapat dicari menggunakan rumus sebagai berikut:

$$
\begin{aligned}
& S E=(S R) \times(R 2) \\
& S E=100 \% \times 0,187 \\
& S E=18,70 \%
\end{aligned}
$$

Berdasarkan hasil perhitungan di atas, dapat diketahui bahwa sumbangan efektif dari disiplin belajar dapat berperan dalam meningkatkan hasil belajar matematika sebesar $18,70 \%$, sedangkan sisanya sebesar $81,30 \%$ dipengaruhi oleh faktor lain. Hal itu sejalan dengan pendapat Bizimana (2017: 51) yang menyatakan bahwa "student academic achievement is not only influence by discipline but by other factors. It was pointed out such as student attitude toward school, motivation, family, societal influence, and inadequate instructional materials among others greatly affect their academic performance." Maksudnya adalah prestasi akademik siswa tidak hanya dipengaruhi oleh disiplin tetatpi juga faktor lain. Faktor - faktor seperti sikap siswa terhadap sekolah, motivasi, keluarga, pengaruh sosial, dan bahan ajar yang tidak memadai antara lain sangat memengaruhi prestasi akademik siswa.

Berdasarkan penelitian dan perhitungan yang telah dilakukan, dapat diketahui bahwa disiplin belajar memiliki pengaruh terhadap hasil belajar matematika. Hal ini sejalan dengan penelitian yang dilakukan oleh Rusni \& Agustan (2018: 8) yang menyatakan bahwa adanya pengaruh yang positif dan signifikan kedisiplinan belajar terhadap hasil belajar matematika sekolah dasar yang dibuktikan dengan hasil koefisien regresi sebesar $10,82 \%$. Hasil penelitian ini sejalan dengan penelitian yang telah dilakukan oleh Kosasih (2018: 112) yang menyatakan bahwa disiplin belajar berpengaruh positif dan signifikan terhadap hasil belajar siswa kelas V. Hal itu diperkuat dengan penelitian yang telah dilakukan oleh Odoyo, Agak, dan Kabuka (2016: 168) yang menyatakan bahwa "discipline relates positively with academic performance $(R=.480 ; p<.230)$. this implies that an increase in discipline has a corresponding increase in academic performance." Maksudnya adalah disiplin berhubungan positif dengan prestasi akademik $r(0,480)$ dan $R^{2}(0,230)$, hal ini menyiratkan bahwa peningkatan disiplin juga meningkatakn prestasi akademik. Dari uraian di atas dapat dikatakan bahwa semakin tinggi disiplin belajar siswa, maka akan semakin tinggi pula hasil belajar matematika siswa. Begitu pun sebaliknya, semakin rendah disiplin belajar siswa, maka akan semakin rendah pula hasil belajar siswa. 


\section{SIMPULAN}

Berdasarkan hasil penelitian mengenai disiplin belajar dan hasil belajar matematika siswa kelas V SDN se-Kecamatan Klirong tahun ajaran 2020/2021 dapat ditarik kesimpulan sebagai berikut.

1. Disiplin belajar berpengaruh sebesar $18,70 \%$ terhadap hasil belajar matematika siswa kelas V SDN se-Kecamatan Klirong tahun ajaran 2020/2021. Semakin tinggi disiplin belajar siswa, maka akan semakin tinggi pula hasil belajar matematika siswa, dan begitupun sebaliknya.

2. Sumbangan efektif variabel disiplin belajar yaitu sebesar $18,70 \%$ dan sisanya sebesar $81,30 \%$ dipengaruhi oleh faktor lain.

\section{DAFTAR PUSTAKA}

Ariefiani, M.N. (2013). Hubungan Disiplin Dengan Hasil Belajar Siswa Pada MataPelajaran Pengolahan Makanan Indonesia 1 Di SMK Negeri 9 Padang. Jurnal Artikel Pendidikan Kesejahteraan Keluarga FT UNP, Padang, 1-15

Bizimana, A. (2017). Students's Academic Performance In Rwanda's Secondary School: A Case Study Of Nyabihu District. Research Project Education Of Mount Kenya University, Rwanda.

Kosasih, N.H. (2018). Pengaruh Disiplin Belajar Terhadap Hasil Belajar Siswa Kelas V Sekolah Dasar Di Kecamatan Cibeuyeng Kaler Kota Bandung. Skripsi Di Publikasi Unpas, Bandung.

Novaliyosi., \& Hadi, S. (2019). TIMSS Indonesia (Trends In International Mathematics And Science Study. Prosiding Seminar Nasional \& Call For Papers Jurusan Matematika Universitas Siliwangi, Bandung, 562-569.

Odoyo, S.N., Agak, J.O., Kabuka, E.K. (2016). Impact Of Discipline On Academic Performance Of Pupils In Public Primary School In Muhoroni Sub-County, Kenya. Journal Of Education And Practice, Vol.7, No.6, Maseno University, Kenya.

Rusni. \& Agustan. (2018). Pengaruh Kedisiplinan Belajar Terhadap Hasil Belajar Matematika Siswa Di Sekolah Dasar. Jurnal Riset Pendidikan Dasar Pascasarjana Unismuh, Makassar, 1(1), 1-9.

Priyatno, D. (2012). Belajar Cepat Olah Data Statistik dengan SPSS. Yogyakarta: Andi Yogyakarta.

Riduwan \& Sunarto. (2013). Pengantar Statistika untuk Penelitian Pendidikan, Sosial, Ekonomi, Komunikasi, dan Bisnis. Bandung: Alfabeta.

Sobur, A. (2016). Psikologi Umum. Cetakan Ke-6 Bandung: Pustaka Setia.

Sujadi, I., \& Wiyoto, J. (2011). Pemanfaatan Matematika Rekreasi dalam Pembelajaran Matematika di SD. Jakarta : Kemdikbud.

Undang-Undang Republik Indonesia No. 20 Tahun 2003 tentang Sistem Pendidikan Nasional.

Wahyudi. (2015). Panduan Pembelajaran Matematika Sekolah Dasar (Untuk Guru dan Calon Guru SD). Surakarta: UNS Press. 